\title{
Polysel: An Environmental-Friendly CI Engine Fuel
}

Navid Pourvosoghi ${ }^{a, \dagger}$, Pouya Mohammadi ${ }^{\mathrm{b}, \dagger}$, Sayed Amir Hossein Golic, Ali M. Nikbakht ${ }^{\mathrm{a}}$, Samad Jafarmadar ${ }^{\mathrm{d}}$, Mohsen Pakzad ${ }^{\mathrm{b}, \mathrm{e}}$, Meisam Tabatabaei ${ }^{\mathrm{b}, \mathrm{f}, *}$

${ }^{a}$ Dept. of Mechanical Engineering in Farm Machinery, Urmia University, P.O Box: 165, Urmia, Iran.

${ }^{b}$ Biofuel Research Team (BRTeam), Karaj, Iran.

${ }^{c}$ Food Science and Technology Department, College of Agriculture, Isfahan University of Technology, 8415683111 Isfahan, Iran.

${ }^{d}$ Department of mechanical Engineering, Urmia University, Urmia, Iran.

e Irankhodro Co., Tehran, Iran

${ }^{f}$ Microbial Biotechnology Department, Agricultural Biotechnology Institute of Iran (ABRII), Agricultural Research, Education, and Extension Organization (AREEO), 31535-1897 Karaj, Iran.

${ }^{\dagger}$ These authors contributed equally.

*Corresponding Author:

Assist. Professor Dr. Meisam Tabatabaei

Biofuel Research Team (BRTeam),

Microbial Biotechnology and Biosafety Department

Agricultural Biotechnology Research Institute of Iran (ABRII)

Fahmideh Blvd., 31535-1897,

Mahdasht Road, Karaj, Iran

Email address: meisam_tab@yahoo.com

Phone Number: +98-2612703536

Fax Number: +98-2612704539

www.brteam.ir 


\begin{abstract}
Biodiesel was produced herein from the oil contained in waste spent bleaching earth (SBE), an environmental pollutant generated through the refining processes of edible oils in oil extraction plants. To further increase waste utilization, waste expanded polystyrene (EPS) was also dissolved in SBE biodiesel $(0,2.5,5$, and $7.5 \mathrm{~g} / 100 \mathrm{ml})$. Performance parameters and emission characteristics of 5\% blend of EPS-SBE biodiesel and diesel were then investigated in a naturally aspirated diesel engine. The results obtained demonstrated that polymer-free SBE-B5 at $1600 \mathrm{rpm}$ and full load led to enhanced brake power and brake mean effective pressure by approximately $1.5 \%$. Moreover, the emitted $\mathrm{HC}, \mathrm{CO}$, and smoke were decreased by over $40 \%, 80 \%$, and $20 \%$, respectively, with polymer inclusion at $2.5 \mathrm{~g} / 100 \mathrm{ml}$ in SBE-B5 at maximum speed of $2600 \mathrm{rpm}$ and full load (280 N.m). While the optimal polymer inclusion level of $2.5 \mathrm{~g} / 100 \mathrm{ml}$ had subtle impacts on engine performance parameters. The findings of the present study could be of great interest to waste valorization industries since an integrated strategy was offered to simultaneously handle two environmental pollutants (SBE oil and EPS wastes) while a more environmentally-friendly fuel blend (i.e., SBE-B5 containing $2.5 \mathrm{~g}$ EPS/100 ml) was also achieved.
\end{abstract}

Keywords: Biodiesel, spent bleaching earth (SBE) oil, polymer wastes, engine operation characteristics, emissions 


\section{Introduction}

Alternative fuels are becoming increasingly important due to environmental and energy concerns [1]. Among renewable energy carriers, biodiesel due to its non-toxic and biodegradable characteristics is highly regarded as a promising alternative to petroleum diesel fuel. Any types of feedstock which contains free fatty acids and/or triglycerides such as vegetable oils, waste cooking oil, animal fats and waste greases can be converted into biodiesel. The most common method to produce biodiesel is transesterification of an oil feedstock with an alcohol (methanol or ethanol) in the presence of a catalyst (homogeneous or heterogeneous) or without the application of catalysts as in the supercritical fluid method [2]. Several blends of biodiesel-petroleum diesel fuel have been proved to have the potential to partially, or even totally, replace diesel in diesel engines [3-5]. Despite all its great advantages such as enhanced biodegradation, reduced toxicity and lower emission profile, biodiesel production cost still remains a challenge in many parts of the world. The cost of raw materials accounts for as much as $78 \%$ of the total production cost [6]. Using non-edible oil resources as feedstock for biodiesel production is also restricted as it could also lead to a competition for agricultural lands which could consequently indirectly affect food security [7]. Therefore, to reduce the production cost and to promote the widespread application of this valuable fuel, seeking economic feedstock especially those of waste origin is critical. ${ }^{1}$
${ }^{1}$ Abbreviations
Bmep Brake mean effective pressure (MPa) SBE Spend bleaching earth
Bte Brake thermal efficiency
SBE0 B5 (0 g polymer in $100 \mathrm{ml} \mathrm{SBE}$ biodiesel)
$\mathrm{CO}$ Carbon monoxide (\%)
SBE2.5 B5 (2.5 g polymer in $100 \mathrm{ml}$ SBE biodiesel)
$\mathrm{CO}_{2} \quad$ Carbon dioxide (\%)
SBE5 B5 (5 g polymer in $100 \mathrm{ml} \mathrm{SBE}$ biodiesel)
$\mathrm{HC}$ Hydrocarbons (ppm)
SBE7.5 B5 (7.5 g polymer in $100 \mathrm{ml}$ SBE biodiesel)
$\mathrm{O}_{2} \quad$ Oxygen $(\%)$ 
Waste vegetable oil remained in spent bleaching earth (SBE) during the crude oil bleaching process is a potential candidate for biodiesel production that has been overlooked in the past [8]. As a rough estimation, $1.2-1.6 \mathrm{~kg}$ of SBE is generated per metric ton of edible oil produced in an oil refinery plant. It is reported that SBE contains as much as $20-40 \mathrm{wt} \%$ oil, fat and colored pigments and that this waste may present a fire hazard if not stored or disposed properly [9]. Currently, only a small fraction of SBE is recovered and is mostly disposed of at landfills. Having considered the world edible oil production of 128.2 million metric tons and that $1.2-1.6 \mathrm{~kg}$ of SBE are generated per metric ton of edible oil produced, the annual global generation of SBE is estimated between 1.5 and 2.0 million tons posing a serious environmental concern [8]. It is worth quoting that large-scale extraction of SBE oil in oil refineries for biodiesel production requires its own logistics which could impose some additional cost on the biodiesel production process. However, given the huge quantity of this waste feedstock, the above-mentioned environmental threats posed and, the fact that utilizing new non-food oil feedstocks is of crucial importance in the future of biodiesel industry, the logistical costs involved should be tolerated.

On the other hand, during last decades, worldwide increase of population together with the requirements of the modern life style has led to a dramatic increase in the generation of waste polymers (mainly plastics) [10]. Millions of tons of these waste materials are generated every year. The U.S. alone generated 251 million tons of municipal solid wastes in 2006, out of which plastics accounted for $11.7 \mathrm{wt} \%$ or 29.5 million tons. In addition, the U.S generates approximately 7.6 billion tons of commercial and industrial wastes each year that also contains a considerable quantity of plastics [11]. Among commercial polymers, polystyrene (PS) is widely used in buildings, structures and packaging sections and accounts for $22 \mathrm{wt} \%$ of the plastics consumed globally. Using PS as a fuel in diesel engines is an 
attractive option for energy recovery from waste plastics. PS can never be burned in a diesel engine in its original form but can be dissolved in a solvent to produce a fuel mixture [12].

Biodiesel due to its unique properties could be an excellent choice as a solvent. It has proved that expanded polystyrene (EPS) as an amorphous and linear PS with a density of 17 $\mathrm{kg} / \mathrm{m}^{3}$ and a molecular weight of between 160,000 and 260,000 , is soluble in biodiesel through physical and chemical treatments [13]. In a study, PS used in packing peanuts was dissolved in biodiesel and was found as a viable fuel [11]. Kuzhiyil and Kong also evaluated energy recovery from PS wastes in biodiesel and conducted tests on a diesel engine. Their findings showed a decrease in engine power by adding blends of PS to biodiesel at the percentages higher than $5 \%$ and that the observed increases in all the emissions recorded were highly correlated to PS concentration [11]. Mohammadi et al. (2012) achieved a considerable emissions reduction by using B5 fuel in which $50 \mathrm{~g} / \mathrm{l}$ polystyrene was dissolved. They found out that despite $3.6 \%$ reduction in brake power, a significant decrease in brake specific fuel consumption $(8.5 \%)$ and increase in brake thermal efficiency $(9.8 \%)$ were achieved at maximum rated power and speed operation condition of the engine. Furthermore, sustainable reductions of $\mathrm{CO}, \mathrm{CO}_{2}, \mathrm{NOx}$, and soot as the major exhaust emissions were recorded [12].

\subsection{Objectives of the study}

In this study, an effort was made to utilize waste EPS by dissolution in SBE biodiesel $(0,2.5,5$, and $7.5 \mathrm{~g} / 100 \mathrm{ml})$. Furthermore, the feasibility of using SBE biodiesel as a partial replacement for fossil diesel was evaluated. In view of this, experiments were conducted on a single-cylinder, four-stroke, direct injection diesel engine operated on various fuel blends at optimum engine parameters. Finally, the results obtained were compared with baseline data and analyzed. 


\section{Experimental setup and procedure}

\subsection{SBE biodiesel production}

SBE was provided by Naz oil company (Isfahan, Iran). The oil adsorbed in SBE was obtained by solvent extraction method as previously described by Sahafi et al (2015) [9]. More specifically, the bleaching earth was exposed to n-hexane at ratio of 1:2 and mixed at $3000 \mathrm{rpm}$ for $2 \mathrm{~h}$ at room temperature. Eventually, solid particles were removed from the extract by paper filtration and the oil was separated from the solvent using a rotary vacuum evaporator. The main challenge for biodiesel production from SBE oil is its high free fatty acids (FFA) content (8\%) reducing the efficiency of the transesterifcation reaction in converting the feedstock into biodiesel. Therefore, to achieve maximal biodiesel yield, a twostep approach with acid-catalyzed esterification (pretreatment) and alkaline catalyzed transesterification was used for biodiesel production to ensure an efficient conversion of FFA into biodiesel [9]. Briefly, the pretreatment process was first carried out with the methanol-tooil ratio of $0.3(\mathrm{v} / \mathrm{v})$ in the presence of $1 \% \mathrm{H}_{2} \mathrm{SO}_{4}(\mathrm{v} / \mathrm{v})$ as an acid catalyst for $1 \mathrm{~h}$ at $60{ }^{\circ} \mathrm{C}$. Biodiesel was then produced from the pre-treated SBE oil with methanol and an alkali catalyst $(\mathrm{KOH})$ in a stirred tank reactor at $60{ }^{\circ} \mathrm{C}$ for $1 \mathrm{~h}$. After the reaction, the mixture was allowed to settle for $1 \mathrm{~h}$ and the methanol-water fraction separated on the top was removed. The acid value of the bottom phase was determined and if the value was measured at above $0.5 \mathrm{mg} \mathrm{KOH} / \mathrm{g}$, the pretreatment step was repeated before proceeding to the transesterification reaction. In order to compare the properties of SBE biodiesel produced $v s$. waste cooking oil biodiesel, their properties were estimated using "Biodiesel Analyzer $\subset$ Ver. 1.1" (available on "http://www.brteam.ir/biodieselanalyzer") [15]. 


\subsection{Fuel samples preparation}

Four different levels of waste EPS used in building materials (i.e. 0, 2.5, 5, $7.5 \mathrm{~g}$ ) were dissolved in $100 \mathrm{ml}$ of the biodiesel produced from SBE oil (SBE0, SBE2.5, SBE5 and SBE7.5, respectively). At lower temperatures, dissolution of polystyrene in biodiesel was incomplete leading to reversible reactions. Therefore, a heating treatment of $60{ }^{\circ} \mathrm{C}$ was employed while dissolving the waste EPS. This was followed by inclusion of commercial acetone as a co-solvent to achieve a secure and robust dissolution $[12,16]$. These biodiesel samples containing waste EPS were blended with diesel to make B5 blends. Engine experiments were run with EPS-biodiesel-diesel, neat B5 and diesel samples.

\subsection{Engine set-up}

The experiments were conducted on a four cylinder, four-stroke and turbocharged direct injection diesel engine located in IDEM Co. (Tabriz, Iran). The engine specifications are detailed in Table 1 and the experimental procedure including the engine test set-up is shown in Figure 1. Engine test was performed with a 13 mode test cycle. An AVL DiCom4000 gas analyzer was used to measure $\mathrm{NOx}, \mathrm{CO}, \mathrm{HC}$ and $\mathrm{CO}_{2}$ using non-dispersive infrared gas analysis (NDIR). Oxygen $\left(\mathrm{O}_{2}\right)$ concentration was evaluated through the exhaust manifold using the electrochemical method. The sensor of the analyzer was exposed to the exhaust gas and the observations were recorded. Smoke was measured using an AVL 415S smoke meter. Table 2 tabulates the measurement accuracy of the instruments used in the experiments for various parameters.

\subsection{Engine performance and combustion characteristics}

Engine performance parameters (i.e., brake power, torque, brake specific fuel consumption, brake thermal efficiency, and brake mean effective pressure) were also calculated at six levels of speed and full load [12, 13, 16-19]. The net heat release rate and the 
mass fraction burned were used as the basis for determining ignition delay and combustion duration [20]. More specifically, the start of combustion is the crank angle location where the minimum heat release occurs prior to positive heat release after fuel injection. Hence, the crank angle difference between the start of injection and this above-mentioned definition of the start of combustion was used to determine ignition delay. In the same way, combustion duration was defined as the crank angle difference between this definition of the start of combustion and the end of combustion, i.e., 90\% mass fraction burned location [20].

\section{Results and Discussions}

\subsection{Fuel properties}

Physicochemical properties of SBE oil in comparison with waste cooking oil are tabulated in Table 3. Lower oxidation stability index and higher free fatty acid are the crucial drawbacks of SBE oil when compared with waste cooking oil. SBE biodiesel was physically and chemically analyzed based on the standard methodology of the American Society for Testing and Materials (ASTM). Table 4 presents the main properties of the produced SBE biodiesel fuel which are in agreement with ASTM D6751 standard values. Moreover, some other properties of SBE biodiesel estimated by "Biodiesel AnalyzerC Ver. 1.1" were compared with those of waste cooking oil biodiesel (Table 5). As shown, the physical properties of SBE biodiesel are close to those of waste cooking oil biodiesel.

\subsection{Engine performance}

The effects of adding SBE oil biodiesel and its blends containing different ratios of dissolved waste polystyrene to diesel fuel on engine performance characteristics (i.e. brake power, torque, brake specific fuel consumption, brake thermal efficiency, brake mean effective pressure), emissions ( $\mathrm{NOx}, \mathrm{CO}, \mathrm{O}_{2}, \mathrm{CO}_{2}, \mathrm{HC}$ and, $\mathrm{PM}$ [soot and smoke]) and exhaust gas temperature $\left({ }^{\circ} \mathrm{C}\right)$ in an unmodified diesel engine were studied. The results 
obtained were compared with the corresponding data for diesel fuel as blank. Among the different speed levels tested, only 1600 and $2600 \mathrm{rpm}$ were reported to facilitate data presentation. Moreover, the former was the speed at which the highest torque was achieved while the latter was the maximum engine speed.

\subsubsection{Engine Torque}

As shown in Figure 2a, the maximum torque was obtained at $1600 \mathrm{rpm}$ for all types of fuel blends. The torque value obtained for SBE0 (B5) was higher than that of diesel fuel. A contributing factor here could be a more complete combustion. This could also be comprehended by considering the increasing $\mathrm{CO}_{2}$ emission when SBE0 (B5) was included into diesel fuel (Fig. 3b). This could be ascribed to the high oxygen content of SBE biodiesel [12]. Moreover, it is worth quoting that physical properties of fuels including biodiesel could affect the injection system and consequently the engine performance parameters [21]. Accordingly, a potential reason leading to such improvement could be the higher viscosity of biodiesel, which may affect the engine brake effective power especially in full-load conditions. In fact, the higher viscosity of biodiesel increases the mixture momentum and consequently penetration depth in the cylinder. It is worth quoting that too high viscosity and surface tension could adversely affect fuel atomization, droplet breakup and spray dispersion during the injection process, leading to higher rate of wall impingement and incomplete combustion. Furthermore, the maximum torque was deteriorated as a result of ESP inclusion (Fig. 2a). This could be attributed to the lower heating value of the EPS and acetone as previously reported by Mohammadi et al. (2013) as well [13].

\subsubsection{Brake Power}

Figure $2 \mathrm{~b}$ presents the variations in brake power at full-load for the different fuel compositions tested. The results obtained revealed that brake power was higher for SBE0-B5 fuel than that of diesel fuel. This was in line with the result of the study conducted by Widyan 
et al. where they reported increased power as much as of $70 \%$ when pure biodiesel was used in comparison with diesel fuel [22]. They stressed that the higher fuel mass flow and viscously of biodiesel and its blends resulted in the power increase. On the contrary, Murillo et al. recorded loss of power $(7.14 \%)$ when biodiesel was compared with diesel on a 3cylinder, naturally aspirated, submarine diesel engine at full load [23]. In their study, the heating value of biodiesel was measured at about $13.5 \%$ lower than that of diesel. Therefore, it could be concluded that in that study, the lower heating value and the higher viscosity resulted in the power loss due to bad fuel injection atomization [24] and low combustion efficiency. As for the other B5 blends tested in the present study i.e. SBE2.5, SBEE5, and SBE7.5, brake power was found to be lower than that of the diesel fuel. These findings were entirely consistent with those of Mohammadi et al. (2012) [12] and could be attributed to the lower torque of these fuel blends.

\subsubsection{Brake Specific Fuel Consumption}

The variations observed in brake specific fuel consumptions (bsfc) at different engine speeds and full-load condition are depicted in Figure 2c. As shown, at $1600 \mathrm{rpm}$ and fullload, bsfc of SBE5 and SBE7.5 B5 fuels were found to be higher by $4.28 \%$ and $0.23 \%$ than that of the diesel fuel, respectively. Basically, bsfc is inversely associated with power and as the power decreases, the specific fuel consumption increases and vice versa [25, 26]. Similarly, Labeckas and Slavinskas claimed that the higher fuel consumption of the biodiesel blends could be related to its lower heating value [27]. Another reason for the increase in Bsfc when using SBE5 and SBE7.5 B5 may be a change in the combustion timing caused by the biodiesel's higher cetane number as well as injection timing alterations [28]. To the contrary, the bsfc of SBE2.5 was lower than that of the diesel fuel by $1.34 \%$ because of the more complete combustion achieved.

\subsubsection{Brake Thermal Efficiency}


Brake thermal efficiency (bte) is the ratio between the power output and the energy introduced through fuel injection, while the latter is the product of the mass flow rate of the injected fuel and its heating value [29]. The Bte values of the engine fuelled with diesel, SBE0, SBE2.5, SBE5 and SBE7.5 B5 blends are shown in Figure 2d. The Bte values obtained for all the B5 fuel blends at $1600 \mathrm{rpm}$ and full load, except for SBE2.5, were less than that of the neat diesel fuel. This could be ascribed to the lower heating value of biodiesel. On the contrary, in a number of studies like that of Buyukkaya, it has been argued that Bte of the engine was improved by increasing biodiesel concentration in the blend [28]. The possible reason for such outcome could be the additional lubricity provided by the biodiesel. In the present study, at the speed of $2600 \mathrm{rpm}$ and full load, bte was generally decreased by EPS inclusion but was shown to have an increasing trend by increasing EPS concentration. This could also be explained by the fact that EPS inclusion slightly improved the heating value of the fuel blend.

\subsubsection{Brake Mean Effective Pressure}

Figure 2e presents the brake mean effective pressure (bmep) of the engine for all the tested fuel blends. The results obtained showed that bmep value decreased for all B5 fuels excluding SBE0 when compared to the neat diesel fuel. More specifically, at the speed of $1600 \mathrm{rpm}$, bmep for SBE0 fuel was measured $1.48 \%$ higher than that of diesel fuel. These findings were in agreement with those of Mohammadi et al. who also investigated several biodiesel-diesel blends (B5) containing various percentages of EPS in a DI diesel engine and concluded that at full load and at the maximum speed, bmep decreased by up to $5.89 \%$ corresponding to increasing EPS concentration. Moreover, at the speed of $2600 \mathrm{rpm}$, a decreasing trend $(0.12 \%, 2.08 \%, 2.70 \%$, and $3.56 \%)$ was observed for bmep as a result of increasing EPS content (SBE0, SBE2.5, SBE5 and SBE7.5, respectively). 


\subsection{Environmental impacts}

\subsubsection{Availability of wastes}

Recently, with the increasing number of environmental legislations and public concerns about environmental pollutions, industrial commitments to waste treatment and disposal have become imperative [30]. As reported by Kheang et al. (2006), SBE is produced at a rate of about $1 \%$ of that of oil production [14]. Hence, during the year 2014-2015 when oil production was reportedly exceeded 175 million metric tons worldwide (http://www.statista.com/statistics/263978/), about 1.75 million metric tons of SBE was produced and disposed of. SBE contains nearly $40 \%$ oil by weight [30]. It should be noted that only a small fraction of this widely-available oil feedstock generated worldwide is recovered and most of them are disposed of at landfills [8]. The large quantity of SBE disposed of in landfills could potentially cause fires and is also considered a pollution hazard due to the substantial oil content in the earth [14].

On the other hand and as stated earlier, a large quantity of EPS wastes are generated around the world annually as well. Source reduction, waste recovery, reuse, and recycling are examples of waste minimisation strategies [31]. However, EPS recycling feasibility has been seriously questioned economically due to its very low density [12]. EPS could be easily separated from the rest of the waste steam ending up in landfills and be subjected to energy recovery by dissolution in biodiesel [12].

\subsubsection{Emission characteristics}

The variations measured in the particulate matter (smoke and soot), $\mathrm{NOx}, \mathrm{CO}, \mathrm{CO}_{2}$, $\mathrm{O}_{2}$, and exhaust gas temperature $\left({ }^{\circ} \mathrm{C}\right)$ at 1600 and $2600 \mathrm{rpm}$ at full-load of the engine performance are shown in Figure 3.

- $\quad$ Carbone monoxide 
Figure 3a illustrates the exhaust $\mathrm{CO}$ traces for different fuel blends. Generally, CO emission takes place due to a non-complete combustion in which some hydrocarbons are not oxidized to $\mathrm{CO}_{2}$. In this sense, $\mathrm{CO}$ emissions are strongly coupled with $\mathrm{HC}$ emissions since both are the results of low quality combustion. Therefore, the effect of biodiesel on $\mathrm{CO}$ emissions is similar to its effect on $\mathrm{HC}$ emissions. In the present study, $\mathrm{CO}$ emission decreased by blending $5 \%$ of biodiesel to neat diesel fuel. This was also previously confirmed by the findings of Aydin and Bayindir on the effect of B5, B20, B50, B75, B100 and neat diesel on engine [32]. They reported that the minimum CO emission values were observed for B50, B75 and B100 which may be directly attributed to the oxygen content of biodiesel. Moreover, the results obtained in the present study showed that at full load, CO emissions were reduced by approximately $33 \%$ for SBE0, $2.5,5$ and 7.5 . Therefore, the reduction achieved was only ascribed to the inclusion of SBE biodiesel and was not influenced by the dissolved ESP.

\section{- $\quad$ Carbone dioxide}

As demonstrated in Figure 3b, except for SBE7.5, $\mathrm{CO}_{2}$ emission increased for all fuel blends tested. It could be assumed that the main reason for decreasing $\mathrm{CO}_{2}$ emission in case of SBE7.5 fuel was the lower exhaust gas temperature and in-complete combustion (as shown in Fig. 3f). In fact, biodiesel is a low-carbon fuel and has a lower elemental carbon to hydrogen ratio than diesel fuel [28]. Hence, a reduction in $\mathrm{CO}_{2}$ emissions is expected, but backfiring and polymer inclusions were probable reasons led to increased $\mathrm{CO}_{2}$ emission in the present study.

- Oxygen

The oxygen content of the exhaust gases is a fair indicator of how lean or rich the engine is operating. A poor fuel will inherently lead to a larger amount of oxygen in the exhaust manifold. As already discussed, biodiesel contains higher amounts of oxygen, an 
attribute which contributes to complete combustion or in another word, less $\mathrm{O}_{2}$ in the exhaust [17]. As can be seen in Figure 3c, oxygen reduced with increasing the load on the engine, and maximum value of $\mathrm{O}_{2}$ at full load was observed for SBE7.5. As explained earlier, this was caused by the lower exhaust gas temperature and in-complete combustion (Fig. 3f).

\section{- $\quad$ Particulate matter}

Particulate matters (PMs) consist of smoke and soot. The former has diameters ranging from 50 to $1000 \mathrm{~nm}$ and is mainly carbonaceous agglomerates [33], while the latter has diameters ranging from 10 to $80 \mathrm{~nm}$ [34]. Due to the heterogeneous nature of diesel combustion, there is a wide distribution of fuel/air ratios within the cylinder and PMs emissions are attributed to either fuel/air mixtures that are too lean to auto-ignite or to support a propagating flame, or fuel/air mixtures that are too rich to ignite. PMs formation mainly takes place in the fuel-rich zone at high temperature and high pressure, especially within the core region of each fuel spray, and is caused by high temperature decomposition [35]. Figure $3 \mathrm{~d}$ illustrates the soot formation at the exhaust manifold for all the investigated fuel samples. At full load and $1600 \mathrm{rpm}$, soot emissions of the SBE0, SBE2.5, SBE5 and SBE7.5 were $12.5,43,47$ and $50 \%$ lower than that of diesel fuel, respectively. In fact, soot emissions decreased significantly by increasing the EPS concentration. The reducing impact of fuels containing EPS on soot emission can be justified by both the presence of acetone in the fuels and the trapped oxygen molecules in EPS. In fact, soot is dependent on local equivalence ratio and combustion temperature [33]. Moreover, acetone inclusion in fuel led to lower soot emission due to reduction of viscosity, fuel consumption, and burning temperature as well as making homogenous concentration of air-fuel mixture in overall combustion chamber due to the oxygenated solvent [12]. On the other hand, the trapped oxygen molecules in EPS contributed to a more complete combustion and consequently less soot formation $[36,37]$. 
Smoke formation depends on the molecular rate of collisions and the concentration of fuel fragments [3]. Hence, concentration of fuel at the moment of ignition and concentration of available oxygen during combustion are basically effective on the rate of smoke generated. As reported by Tan et al. (2012), biodiesel has a decreasing effect on smoke emission at both low and high engine speeds. In the present study, addition of biodiesel into diesel fuel decreased smoke emitted due to reduced carbon (fewer $\mathrm{C}-\mathrm{C}$ bonds) and increased $\mathrm{O}_{2}$ contents in the blended fuels [3]. The improvement was more obvious at high engine loads when a larger percentage of fuel was burned in the diffusion mode [3].

\section{- $\quad$ Unburned hydrocarbons $(H C)$}

As reported in the literature, $\mathrm{HC}$ behaves like $\mathrm{CO}$ when biodiesel is added to diesel fuel [38]. The findings reported in the literature on the impact of biodiesel addition on HC emissions have been inconsistent $[38,41]$. This was also observed in the present study where at $2600 \mathrm{rpm}$ speed of engine and full load, $\mathrm{HC}$ emission decreased by $14 \%$ and $28 \%$ for SBE0 and SBE2.5 while it significantly increased for higher EPS inclusion rates (Fig. 3g).

- $\quad$ Nitrogen oxides (NOx)

NOx forms as a result of reaction between available $\mathrm{O}_{2}$ and $\mathrm{N}_{2}$ of air at high reaction temperature. Generally, temperature and $\mathrm{O}_{2}$ concentration in the combustion chamber as well as fuel density, ignition delay and equivalence ratio of the fuel have direct impacts on NOx formation [42]. Biodiesel as an oxygenating additive due to its high oxygen content could provide a suitable condition for NOx formation [24, 43]. Nevertheless, there have been controversial reports on the impact of biodiesel blending on NOx emissions. For instance, Dorado et al. found that NOx emissions were reduced by over $32 \%$ for biodiesel produced from waste olive oil using an 8-mode test cycles [44]. On the contrary, Ozsezen et al. reported 22.13 and $6.48 \%$ increases in NOx emissions on a 6-cylinder DI diesel engine for waste palm oil and canola oil biodiesel, respectively [45]. In the present study, at the speed of 
$1600 \mathrm{rpm}$ and full load of the engine, NOx emissions for the SBE0, SBE2.5, SBE5, SBE7.5 and diesel fuels were recorded at 640, 637, 636, 465 and $601 \mathrm{ppm}$, respectively (Fig. 3e). The results obtained showed that NOx emissions were reduced with increasing EPS concentration. There was a $24 \%$ reduction in NOx for SBE7.5 fuel compared to diesel fuel which could be regarded as a remarkable achievement. In a similar research, Kuzhiyil and Kong also reported that NOx emissions were slightly reduced by increasing polystyrene concentrations [11].

\subsection{Exhaust gas temperature}

The variations in exhaust gas temperature $\left({ }^{\circ} \mathrm{C}\right)$ for different fuels as a function of 10 , 25, 50, 75 and 100\% full load is presented in Figure 3h. As presented, exhaust gas temperature $\left({ }^{\circ} \mathrm{C}\right)$ dropped slightly by increasing the EPS concentration. At $1600 \mathrm{rpm}$ and full load condition, exhaust gas temperature $\left({ }^{\circ} \mathrm{C}\right)$ of the SBE0, SBE2.5, 5 and 7.5 were $2.1,1.8,3$ and $5.1 \%$ lower than that of diesel fuel, respectively. Exhaust gas temperature is affected by the changes in ignition delay. In fact, the lower the cetane number of a fuel, the longer the ignition delay period would be. As a result, the comparatively lower cetane number of neat diesel fuel than biodiesel led to longer ignition delay which in turn resulted in a delayed combustion and higher exhaust gas temperature. This finding was in good agreement with those of Aydin and Bayindir who reported that the highest value of exhaust gas temperature $\left(469{ }^{\circ} \mathrm{C}\right.$ ) was observed at $2500 \mathrm{rpm}$ with diesel fuel at full load, whereas the corresponding value with the $\mathrm{B} 20$ blend was at $395^{\circ} \mathrm{C}$ [32].

\subsection{Combustion characteristics}

Figure 4 depicts the pressure of the combustion chamber during the combustion period against crank angle for the best fuel composition in terms of engine performance and emissions, i.e., Polysel (2.5 g/100 ml in SBE-B5) and diesel (as blank) at speed of $2600 \mathrm{rpm}$ 
and full load. The higher pressure, i.e., 0.23 MPa (2.3 bar) (Table 6) achieved at the peak of the curve using Polysel compared with neat diesel was favorable showing higher in-cylinder pressure. Moreover, the curve peaked 0.5 degree earlier for Polysel than diesel. This reflects the fact that the combustion process was advanced leading to a more linear velocity of piston. Moreover, the maximum in-cylinder pressure values for the fuels at both speed of 1600 and $2600 \mathrm{rpm}$ and full load are tabulated in Table 6. Accordingly, it could be observed that the higher amount of maximum in-cylinder pressure of the fuels containing EPS in comparison with diesel and B5 fuel was favorable. This could be attributed to the improving impacts of EPS and acetone content on the combustion.

The variation in the rate of heat release and mass fraction burned vs. crank angle degree after top dead center ( ${ }^{\circ}$ ATDC) for SBE2.5 fuel (i.e., Polysel) at full load and $2600 \mathrm{rpm}$ is presented in Figure 5. Combustion duration (CD) and ignition delay (ID) are shown as well (Fig. 5). Furthermore, maximum rate of heat release, combustion duration, and ignition delay for the fuels are summarized in Table 6. As presented, a lower value for maximum rate of heat release was obtained for B5 fuel compared with diesel. Moreover, increasing EPS content, led to increased maximum rate of heat release. Moreover, the lower ignition delay by using Polysel was also favorable which could be attributed to the higher cetane number of biodiesel. In another word, the comparatively lower cetane number of neat diesel fuel than biodiesel led to longer ignition delay which in turn resulted in a delayed combustion and higher exhaust gas temperature. Combustion duration of SBE0 was found lower than that of diesel at both speeds. In fact, the lower combustion duration as well as lower rate of heat release revealed that biodiesel content decreased the combustion efficiency while the EPS inclusion in the fuel nearly compensated for this reduction in combustion duration due to the improving impacts of EPS and acetone on the combustion process. 


\subsection{Economic assessment}

The overall production cost of any fuel blend including the cost of raw materials, transportation, and energy consumption is to be investigated prior to the scale up process. The cost of inputs for production of biodiesel from SBE oil is detailed in Table 7. Figure 6 presents the share of each input considered in calculating the final price of 11 of SBE biodiesel. As shown, energy consumption cost by contributing $81.5 \%$, (or 1.1 out of 1.35USD), plays the major role in the overall production cost. The remaining cost of 0.25 USD is shared by methanol, SBE oil, and catalyst. The cost of EPS has been ignored as it is available as waste. The high energy cost was attributed to the waste nature of SBE oil, cost of required logistics and transportation, and the fact that biodiesel production process required a multi-washing step to meet the international standards (ASTM D6751). Nevertheless, given the obligation and the cost involved for SBE safe disposal due to its environmentally hazardous nature, oil extraction from SBE followed by biodiesel production could be proposed as an economic process alternative.

\section{Conclusions}

SBE biodiesel is recommended for use as a substitute for petroleum-based diesel not only due to the well-known advantages of biodiesel but also because it is produced from an environmentally hazardous waste i.e. SBE. Moreover, dissolution of waste EPS in such biodiesel as a green recovery method was found of interest in the present study. Performance and emissions results of the diesel engine fueled with dissolved EPS-biodiesel-diesel fuel as B5 revealed that low concentrations of dissolved polystyrene i.e. $2.5 \mathrm{~g} / 100 \mathrm{ml}$ biodiesel remarkably reduced engine emissions. More specifically, $\mathrm{HC}, \mathrm{CO}$ and smoke were decreased by over $40 \%, 80 \%$ and $20 \%$, respectively; with polymer inclusion at $2.5 \mathrm{~g} / 100 \mathrm{ml}$ in SBE-B5 
at maximum speed of $2600 \mathrm{rpm}$ and full load (280 N.m). Optimal polymer inclusion level of $2.5 \mathrm{~g} / 100 \mathrm{ml}$ had subtle impacts on engine performance parameters.

\section{Acknowledgements}

This study was funded by Agricultural Biotechnology Research Institute of Iran (ABRII), Biofuel Research Team (BRTeam), Iran Khodro Diesel Co, and Iran National Science Foundation (INSF). The authors would also like to thank Eng. Seyed Abbas Ghafari and Eng. Abdul Rasoul Ghanbari for their valuable assistance during the course of this study.

\section{References}

[1] Agarwal A, Biofuels (Alcohols and Biodiesel) Applications as Fuels for Internal Combustion Engines. Prog Energ Combust Sci 2007; 33: 233 - 271.

[2] Hasheminejad M, Tabatabaei M, Mansourpanah Y, Khatami far M, Javani A. Upstream and Downstream Strategies to Economize Biodiesel Production. Bioresour Technol 2011; 102: 461 - 468 .

[3] Tan P, Hu Z, Lou D, Li Z. Exhaust Emissions from a Light-Duty Diesel Engine with Jatropha. Biodiesel Fuel Energ 2012; 39: 356 - 362.

[4] Ramadhas A S, Jayaraj S, Muraleedharan C. Use of Vegetable Oils as I C Engine FuelsA Review. Renew Energ 2004; 29: 727-742.

[5] Bautista L, Vicente G, Rodriguez R, Pacheco M. Optimization of FAME Production From Waste Cooking Oil for Biodiesel Use. Biomass Bioenerg 2009; 33: 862-872.

[6] Huzayyin A S, Bawady A H, Rady M A, Dawood A. Experimental Evaluation of Diesel Engine Performance and Emission Using Blends of Jojoba Oil and Diesel Fuel. Energ Convers Manage 2004; 45: 2093-2112.

[7] Kanna G R, Karvembu R, Anand R. Effect of Metal Based Additive on Performance Emission and Combustion Characteristics of Diesel Engine Fuelled with Biodiesel. Appl Energ 2011; 88: 3694-3703.

[8] Huang Y, Chang J. Biodiesel Production from Residual Oils Recovered from Spent Bleaching Earth. Renew Energ 2010; 35: 269-274. 
[9] Sayed Mohammad Sahafi, Sayed Amir Hossein Goli, Meisam Tabatabaei, Ali Mohammad Nikbakht, Navid Pourvosoghi. The reuse of waste cooking oil and spent bleaching earth to produce biodiesel. 2015. Energy Sources, Part A: Recovery, Utilization, and Environmental Effects. In Press.

[10] Achilias D, Roupakias C, Megalokonomos P, Lappas A, Antonakou E. Chemical Recycling of Plastic Wastes Made from Polyethylene (LDPE And HDPE) and Polypropylene (PP). J Hazard Mater 2007; 149: 536-542.

[11] Kuzhiyil N, Kong S. Energy Recovery from Waste Plastics by Using Blends of Biodiesel and Polystyrene in Diesel Engines. Energ Fuel 2009; 23: 3246-3253.

[12] Mohammadi P, Nikbakht A M, Tabatabaei M, Farhadi K, Mohebbi A, Khatami far M. Experimental Investigation of Performance and Emission Characteristics of DI Diesel Engine Fueled With Polymer Waste Dissolved in Biodiesel-Blended Diesel Fuel. Energy 2012; 46: 596-605.

[13] Mohammadi P, Tabatabaei M, Nikbakht A M, Farhadi K, Khatami far M. Castaldi M J. Simultaneous Energy Recovery from Waste Polymers in Biodiesel and Improving Fuel Properties. Waste Biomass Valor 2013; 4:105-116.

[14] Kheang LS, Foon CS, May CY, Ngan MA. A Study of Residual Oils Recovered from Spent Bleaching Earth: Their Characteristics and Applications, Am J Appl Sci 2006; 3 (10): 2063-2067.

[15] Talebi A F, Tabatabaei M, Chisti Y. Biodiesel Analyzer: a user-friendly software for predicting the properties of prospective biodiesel. Biofuel Res J 2014; 1(2): 55-57.

[16] Mohammadi P, Tabatabaei M, Nikbakht A M, Esmaeili Z. Improvement of the cold flow characteristics of biodiesel containing dissolved polymer wastes using acetone. Biofuel Res $\mathrm{J}$ 2014; 2: 26-9.

[17] Lin C, Li R. Engine Performance and Emission Characteristics of Marine Fish-Oil Biodiesel Produced from the Discarded Parts of Marine Fish. Fuel Process Technol 2009; 90: $883-888$.

[18] Rakopoulos D C, Rakopoulos C D, Kakaras E C, Giakoumis E G. Effects of Ethanoldiesel Fuel Blends on The Performance and Exhaust Emissions of Heavy Duty DI Diesel Engine. Energ Convers Manage 2008; 49: 3155-3162.

[19] Arpa O, Yumrutas R, Argunhan Z. Experimental Investigation of The Effects of DieselLike Fuel Obtained From Waste Lubrication Oil on Engine Performance and Exhaust Emission. Fuel Process Technol 2010; 91: 1241-1249.

[20] Bittle JA, Knight BM, Jacobs TJ. Interesting Behavior of Biodiesel Ignition Delay and Combustion Duration. Energ Fuel 2010; 24: 4166-4177. 
[21] Tesfa B, Mishra R, Gu F, Powles N. Prediction Models for Density and Viscosity of Biodiesel and Their Effects on Fuel Supply System in CI Engines. Renew Energ 2010; 35: 2752-2760.

[22] Al-Widyan M I, Tashtoush G, Abu-Qudais M. Utilization of Ethyl Ester of Waste Vegetable Oils as Fuel in Diesel Engines. Fuel Process Technol 2002; 76: 91 - 103.

[23] Murillo S, Miguez J, Porteiro J, Granada E, Moran J. Performance and Exhaust Emissions in the Use of Biodiesel in Outboard Diesel Engines. Fuel 2007; 86: 1765-1771.

[24] Xue J, Grift T, Hansen A. Effect of Biodiesel on Engine Performances and Emissions. Renew Sust Energ Rev 2011; 15: 1098-1116.

[25] Zheng M, Mulenga M, Reader G, Wang M, Ting D, Tjong J. Biodiesel Engine Performance and Emissions in Low Temperature Combustion. Fuel 2008; 87: 714-722.

[26] Gokalp B, Buyukkaya E, Soyhan H S. Performance and Emissions of a Diesel Tractor Engine Fueled with Marine Diesel and Soybean Methyl Ester. Biomass Bioenerg 2011; 35: $3575-3583$.

[27] Labeckas G, Slavinskas S. The Effect of Rapeseed Oil Methyl Ester on Direct Injection Diesel Engine Performance and Exhaust Emissions. Energ Convers Manage 2006; 47: 19541967.

[28] Buyukkaya E. Effects of Biodiesel on a DI Diesel Engine Performance Emission and Combustion Characteristics. Fuel 2010; 89: 3099-3105.

[29] Lapuerta M, Armas O, Rodriguez-Fernandez J. Effect of Biodiesel Fuels on Diesel Engine Emissions. Prog Energy Combust Sci 2008; 34: 198 - 223.

[30] Lara PV, Park EY. Potential application of waste activated bleaching earth on the production of fatty acid alkyl esters using Candida cylindracea lipase in organic solvent system. Enzyme Microb Tech 2004; 34:270-277.

[31] Pollard SJT, Sollars CJ, Perry R. The reuse of spent bleaching earth: a feasibility study in waste minimisation for the edible oil industry. Bioresour Tech 1993; 45: 53-58.

[32] Aydin H, Bayindir H. Performance and Emission Analysis of Cottonseed Oil Methyl Ester in a Diesel Engine. Renew Energ 2010; 35: 588-592.

[33] Su J, Zhu H, Bohac S V. Particulate matter emission comparison from conventional and premixed low temperature combustion with diesel, biodiesel and biodiesel-ethanol fuels. Fuel 2013; 113: 221-227.

[34] Heywood, J.B., 1988. "Internal Combustion Engine Fundamentals", McGraw-Hill, New York. 
[35] Puhan S, Vedaraman N, Ram B V B, Sankarnarayanan G, Jeychandran K. Mahua Oil (Madhuca Indica Seed Oil) Methyl Ester as Biodiesel-Preparation and Emission Characteristics. Biomass Bioenerg 2005; 28: 87-93.

[36] Tormos B, Novella R, Garca A, Gargar K. Comprehensive study of biodiesel fuel for HSDI engines in conventional and low temperature combustion conditions. Renew Energy 2010; 35(2): 368-378.

[37] Labeckas G, Slavinskas S. The effect of rapeseed oil methyl ester on DI diesel engine performance and exhaust emissions. Energy Convers Manage 2006; 47 (13-14): 1954-1967.

[38] Rakopoulos CD, Hountalas DT, Zannis TC, Levendis YA. Operational and environmental evaluation of diesel engines burning oxygen-enriched intake air or oxygenenriched fuels: a review. SAE paper no. 2004-01-2924, 2004.

[39] Lin B, Huang J, Huang D. Experimental study of the effects of vegetable oil methyl ester on DI diesel engine performance characteristics and pollutant emissions. Fuel 2009; 88: 1779-1785.

[40] Monyem A, Van Gerpen JH. The effect of biodiesel oxidation on engine performance and emissions. Biomass Bioenergy 2001; 20: 317-325.

[41] Fontaras G, Karavalakis G, Kousoulidou M, Tzamkiozis T, Ntziachristos L, Bakeas E, et al. Effects of biodiesel on passenger car fuel consumption, regulated and non-regulated pollutant emissions over legislated and real-world driving cycles. Fuel 2009; 88: 1608-1617.

[42] Saravanan S, Nagarajan G, Anand S, Sampath S. Correlation for thermal NOx formation in compression ignition (CI) engine fuelled with diesel and biodiesel. Energ 2012; 42 (1): 401-410.

[43] Usta N. An experimental study on performance and exhaust emissions of a diesel engine fuelled with tobacco seed oil methyl ester. Energ ConversManage 2005; 46: 2373-86.

[44] Dorado M, Ballesteros E, Arnal J, Gomez J, Lopez F. Exhaust Emissions From a Diesel Engine Fueled with Transesterified Waste Olive Oil, Fuel 2003; 82: 1311-1315.

[45] Ozsezen A N, Canakci M, Turkcan A, Sayin C. Performance and Combustion Characteristics of a DI Diesel Engine Fueled with Waste Palm Oil and Canola Oil Methyl Esters. Fuel 2009; 88: 629-636.

[46] Araujo V K W S, Hamacher S, Scavarda L F. Economic Assessment of Biodiesel Production from Waste Frying Oils. Bioresour Technol 2010; 101: 4415-4422.

[47] Kapilakarn K, Peugtong A. A Comparison of Costs of Biodiesel Production from Transesterication. Int Energ J 2007; 8: 1- 6. 


\section{Figure Legends}

Figure 1. The experimental procedure including, SBE biodiesel production, ESP inclusion and the engine test set-up.

Figure 2. Variations in the engine torque (a), brake power (b), bsfc (c), bte (d), and bmep (e) with engine speeds (1600 and $2600 \mathrm{rpm})$ and at full-load using various fuel blends.

Figure 3. Variations observed in $\mathrm{CO}(\mathrm{a}), \mathrm{CO}_{2}(\mathrm{~b}), \mathrm{O}_{2}$ (c), soot (d), $\mathrm{NO}_{\mathrm{x}}(\mathrm{e})$, smoke (f), $\mathrm{HC}$ $(\mathrm{g})$, and exhaust gas temperature $\left({ }^{\circ} \mathrm{C}\right)(\mathrm{h})$ at full-load and different engine speeds of 1600 and $2600 \mathrm{rpm}$.

Figure 4. In-cylinder pressure of the engine fueled with Polysel and diesel vs. crank angle degree at full load and $2600 \mathrm{rpm}$ operation condition.

Figure 5. Variation in the rate of heat release and mass fraction burned $v$ s. crank angle degree ATDC for Polysel fuel at full load and $2600 \mathrm{rpm}$.

Figure 6. The share of each input used in calculating the final price of 11 of SBE biodiesel containing polymer waste. 
Table 1. Engine specifications

Engine model

Induction system

Maximum power

Maximum torque

Bore

Stroke

Compression ratio

Combustion system

Number of cylinders

Number of valves per cylinder

Fuel
OM314LA EUII

Turbocharged

81kW@2800rpm

340N.m@1400-2000 rpm

$97 \mathrm{~mm}$

$128 \mathrm{~mm}$

$17: 1$

4 stroke Direct injection

4. in line, vertical

2

Diesel 
Table 2. Measurements accuracy

\begin{tabular}{lll}
\hline Measuring instruments & Instruments' Model & Accuracy \\
\hline Dynamometer & Pmid company (model E400) & Power, 1 Hp; Torque, \\
& & $1 \mathrm{Nm}$; Speed, 1 rpm \\
Fuel flow meter & Pmid company & $0.01 \mathrm{~kg} / \mathrm{h}$ \\
Airflow meter & ABB Sensyflow P (Germany) & $0.3 \mathrm{~kg} / \mathrm{h}$ \\
$\mathrm{CO}$ & AVL Digas4000 & $0.01 \%$ \\
$\mathrm{CO}_{2}$ & AVL Digas4000 Light & $0.01 \%$ \\
$\mathrm{NOx}$ & AVL DiCom4000 & $1 \mathrm{ppm}$ \\
$\mathrm{Smoke}$ & AVL 415S smoke meter & $1 \mathrm{~m} \mathrm{~g} / \mathrm{m} 3$ \\
Soot & AVL 415S & $1 \mathrm{~B} . \mathrm{N}$ \\
$\mathrm{O}_{2}$ & AVL DiCom4000 & $0.01 \%$ \\
Temperature & Bentley Instruments & $1{ }^{\circ} \mathrm{C}$ \\
\hline Computed & & Uncertainty (\%) \\
parameters & & \\
\hline brake power & & $1 \%$ \\
Bmep & & $0.5 \%$ \\
bsfc, bte, bfce & & $1.4 \%$ \\
\hline
\end{tabular}


Table 3- Physicochemical properties of SBE oil in comparison with waste cooking oil

\begin{tabular}{llll}
\hline Properties & Unit & SBE oil & Waste cooking oil \\
\hline Refractive index $\left(25^{\circ} \mathrm{C}\right)$ & - & 1.4705 & 1.4710 \\
Specific gravity $\left(25^{\circ} \mathrm{C}\right)$ & $\mathrm{kg} / \mathrm{m}^{3}$ & 0.913 & 0.916 \\
Viscosity & $\mathrm{cp}$ & 31.32 & 35.88 \\
$\begin{array}{l}\text { Free fatty acid } \\
\text { (on the basis of oleic acid) }\end{array}$ & $\%$ & 8.32 & 3.64 \\
Oxidation stability index & $\mathrm{h}$ & 0.4 & 4.2 \\
\hline
\end{tabular}


Table 4. Major fuel properties of SBE biodiesel.

\begin{tabular}{lllll}
\hline Fuel property & Unit & $\begin{array}{l}\text { ASTM D6751 } \\
\text { standard } \\
\text { method }\end{array}$ & $\begin{array}{l}\text { ASTM D6751 } \\
\text { standard limits }\end{array}$ & $\begin{array}{l}\text { SBE oil } \\
\text { biodiesel }\end{array}$ \\
\hline Flash point & ${ }^{\circ} \mathrm{C}$ & $\mathrm{D} 93$ & $>130$ & 175 \\
Dynamic viscosity & $\mathrm{mPa} . \mathrm{s}$ in $40^{\circ} \mathrm{C}$ & $\mathrm{D} 445$ & $1.6438-5.1912$ & 4.0955 \\
Density & $\mathrm{g} / \mathrm{cm} 3$ in $40^{\circ} \mathrm{C}$ & $\mathrm{D} 941$ & - & 0.8652 \\
Water content \& sediment & $\% \mathrm{v}$ & $\mathrm{D} 2709$ & $<0.050$ & 0.0195 \\
Acid value & $\mathrm{mg} \mathrm{KOH} / \mathrm{g}$ & $\mathrm{D} 664$ & $<0.8$ & 0.412 \\
Free glycerin & $\% \mathrm{wt}$ & $\mathrm{D} 6584$ & $<0.02$ & 0.011 \\
\hline
\end{tabular}


Table 5. Estimated properties of SBE biodiesel vs. waste cooking oil biodiesel

\begin{tabular}{lll}
\hline Properties & $\begin{array}{l}\text { SBE } \\
\text { biodiesel }\end{array}$ & $\begin{array}{l}\text { Waste cooking oil } \\
\text { biodiesel }\end{array}$ \\
\hline Saturated fatty acids & 16.81 & 17.10 \\
Cetane Number & 43.53 & 43.30 \\
Cloud Point $\left({ }^{\circ} \mathrm{C}\right)$ & 1.45 & 1.10 \\
Oxidation Stability $(\mathrm{h})$ & 4.53 & 4.60 \\
Higher Heating value $\left(\mathrm{kJ}^{\mathrm{k}} \mathrm{kg}^{-1}\right)$ & 39.41 & 39.43 \\
\hline
\end{tabular}


Table 6. The combustion characteristics of the engine fueled with different fuel blends at 1600 and $2600 \mathrm{rpm}$, and full load operation condition

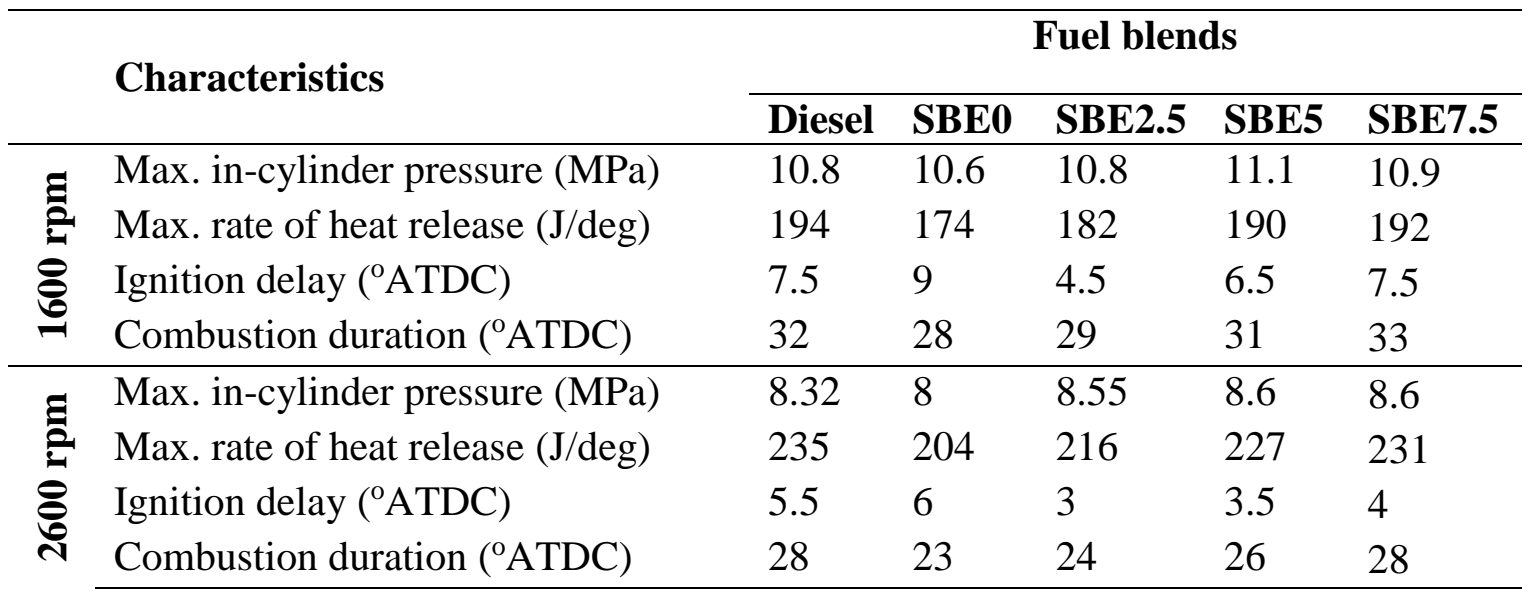


Table 7. The estimated cost of the input materials used for the production of SBE biodiesel containing polymer waste

\begin{tabular}{llll}
\hline Material & Unit & Price (USD) & References \\
\hline Methanol* & $1 \mathrm{~L}$ & 0.07 & {$[45]$} \\
SBE oil & $1 \mathrm{~L}$ & $0.16^{* *}$ & This study \\
Waste EPS & $1 \mathrm{~kg}$ & FOC*** & - \\
Catalyst* & $1 \mathrm{~L}$ & 0.01 & {$[45]$} \\
Energy consumption & $1 \mathrm{kw}$ & 0.009 & {$[46]$} \\
\hline *Transestrification was carried out with $6: 1$ methanol to oil molar ratio and $1 \% \mathrm{wt} / \mathrm{wt} \mathrm{KOH}$ as an alkaline \\
catalyst. \\
**The cost arises from the extraction of oil from SBE. \\
***Free of charge.
\end{tabular}


Figure 1

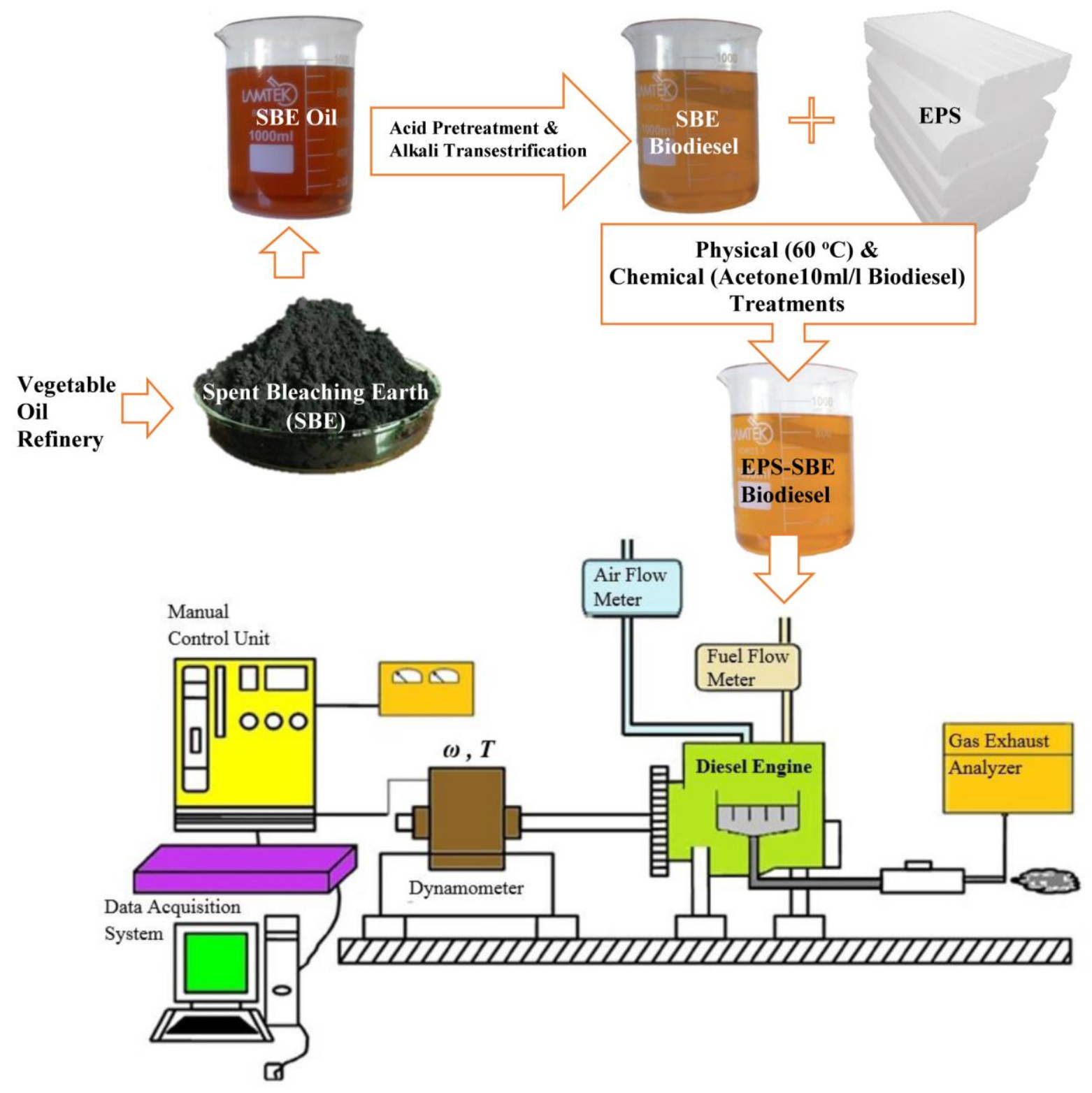


Figure 2

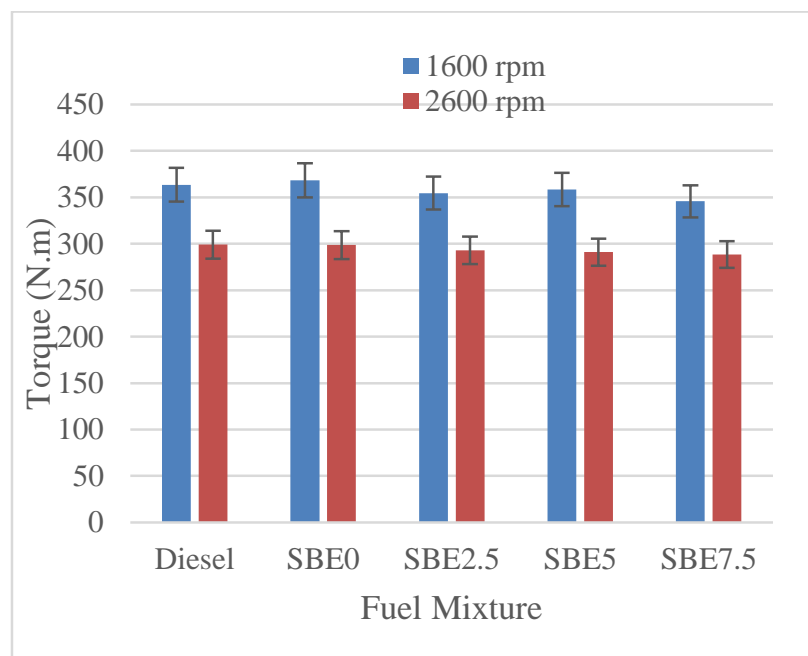

a

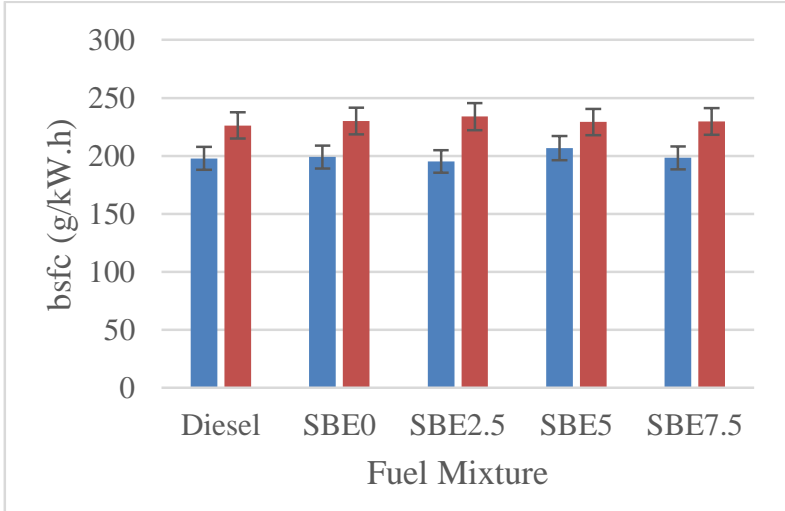

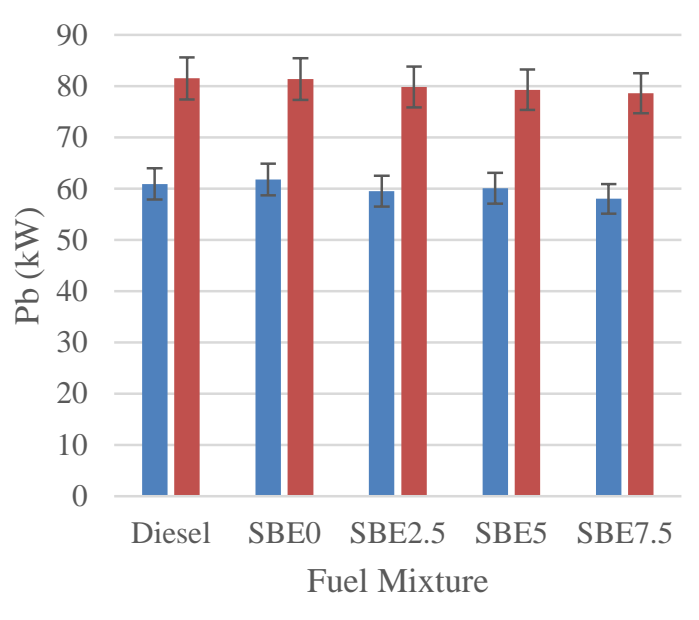

b

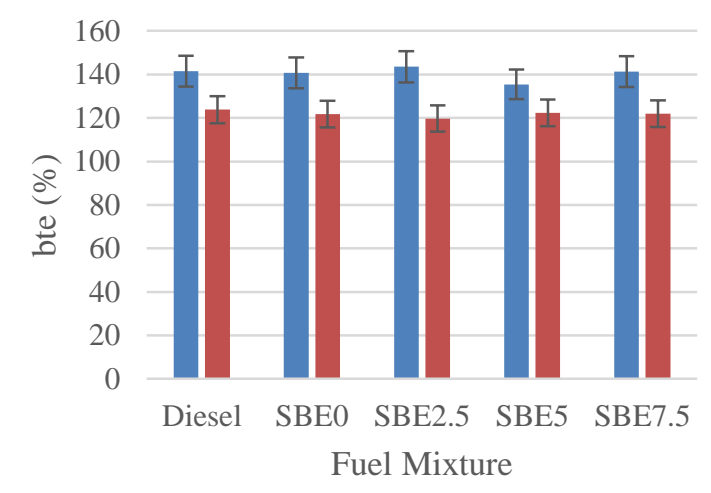

c

d

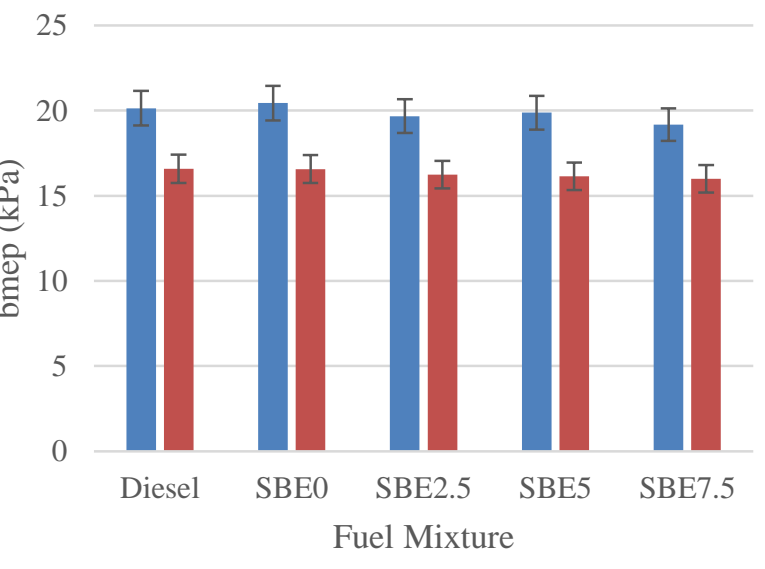

e 
Figure 3

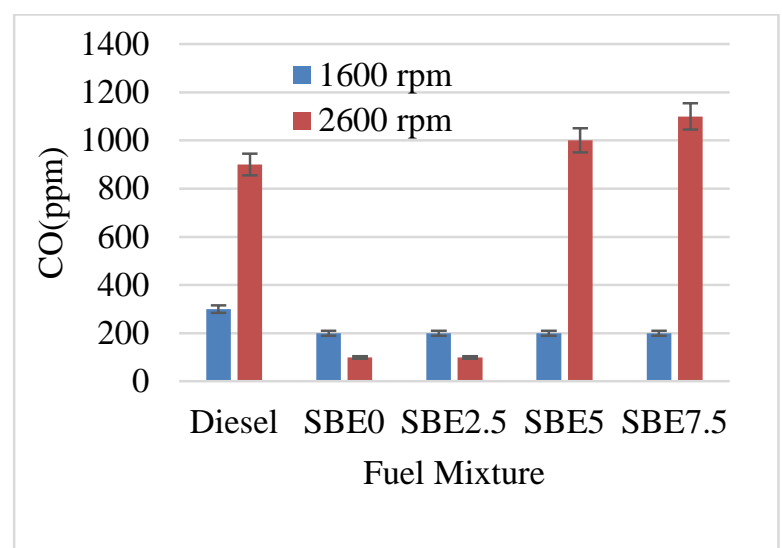

a

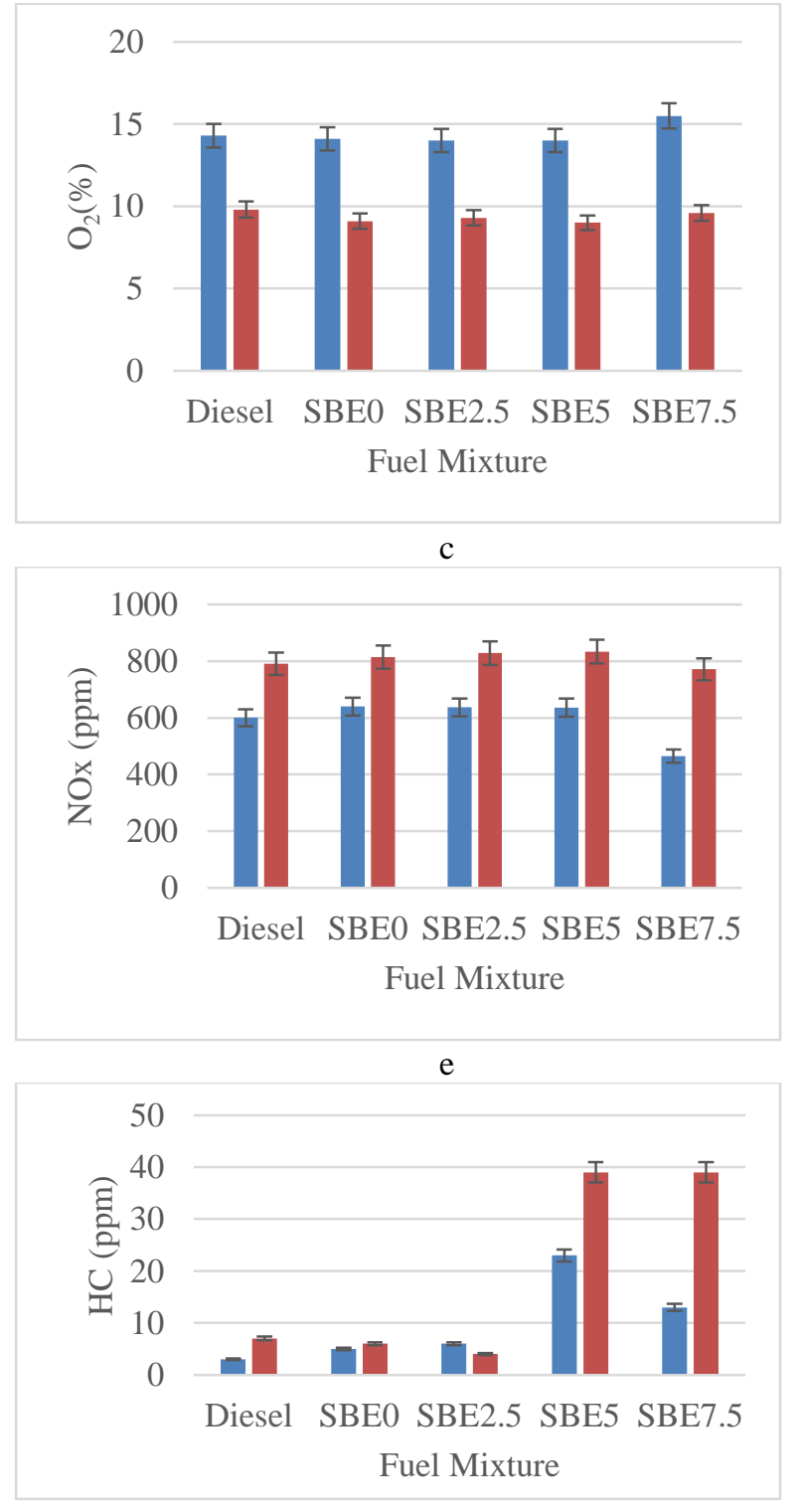

g

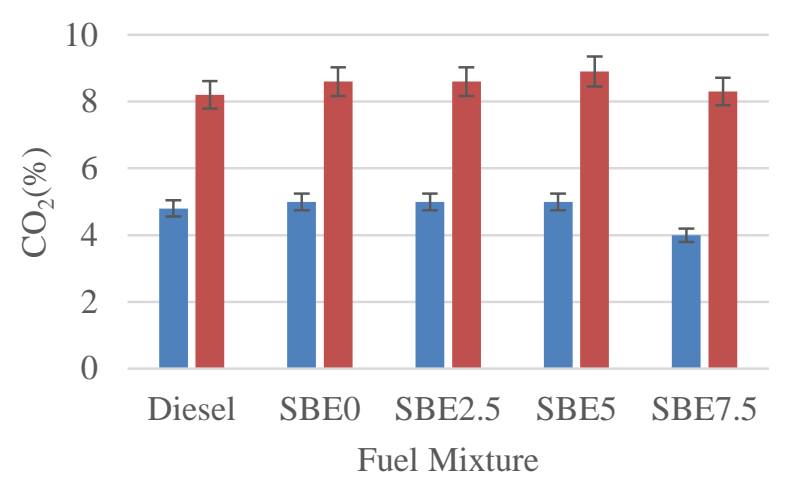

b

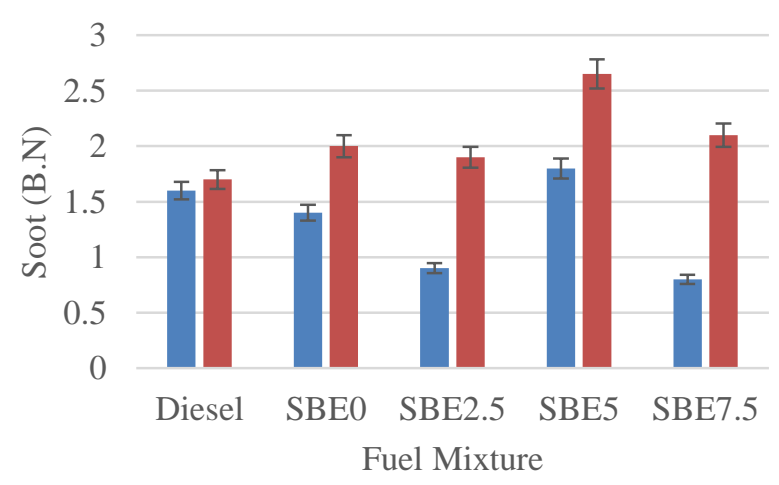

d

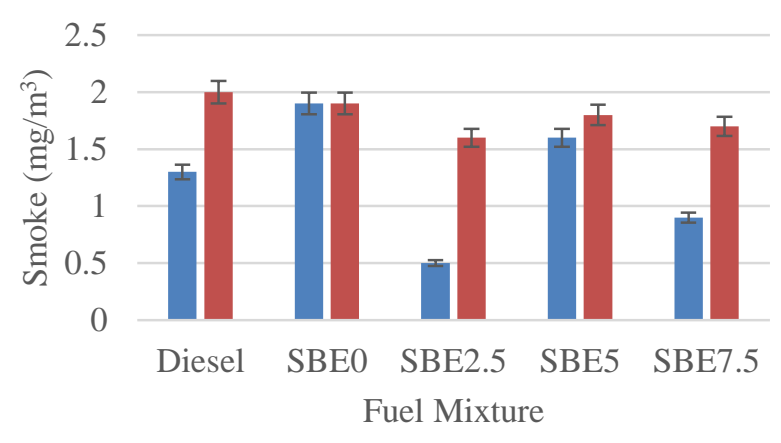

f

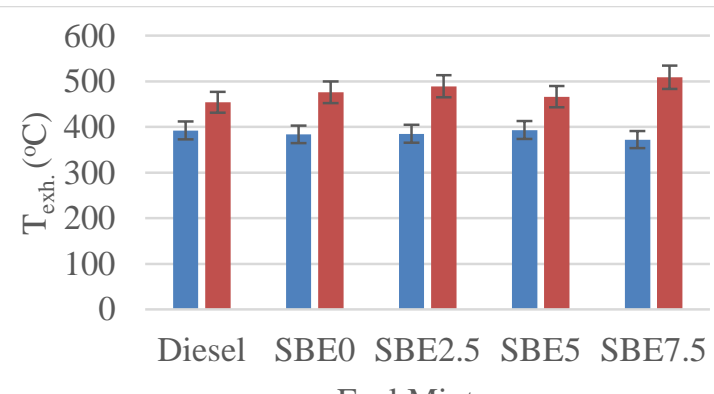

Fuel Mixture 
Figure 4.

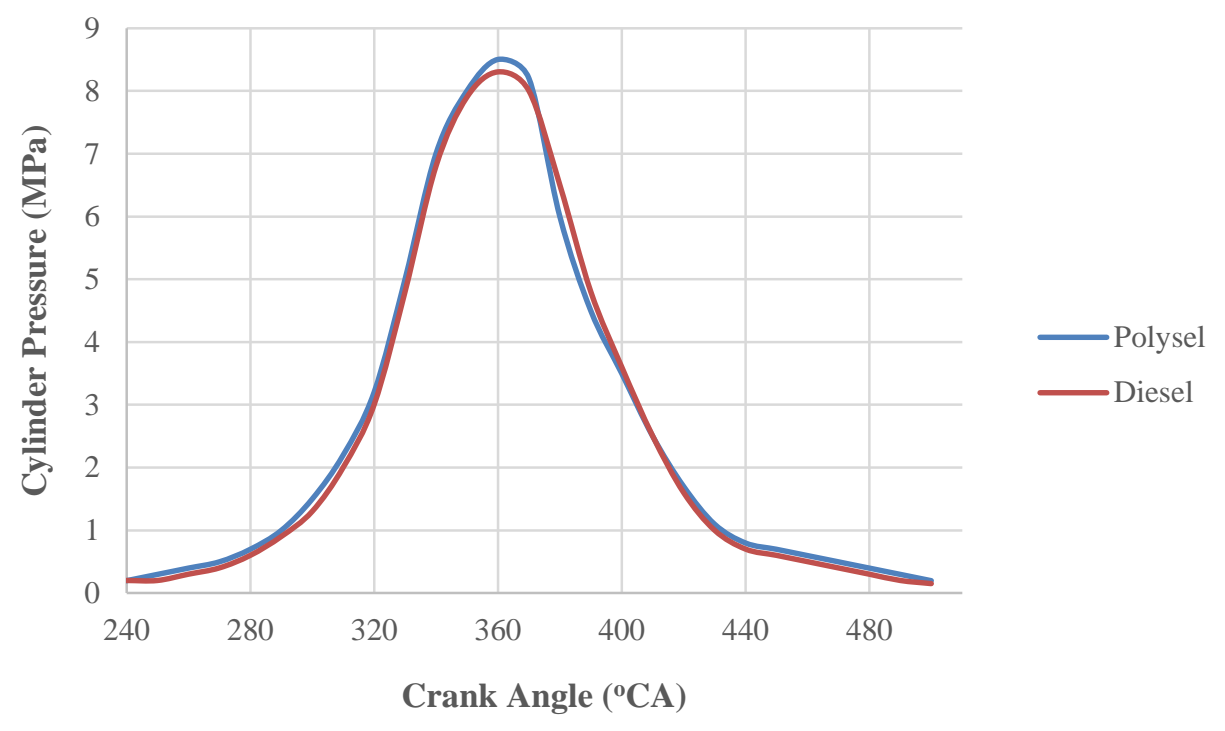


Figure 5.

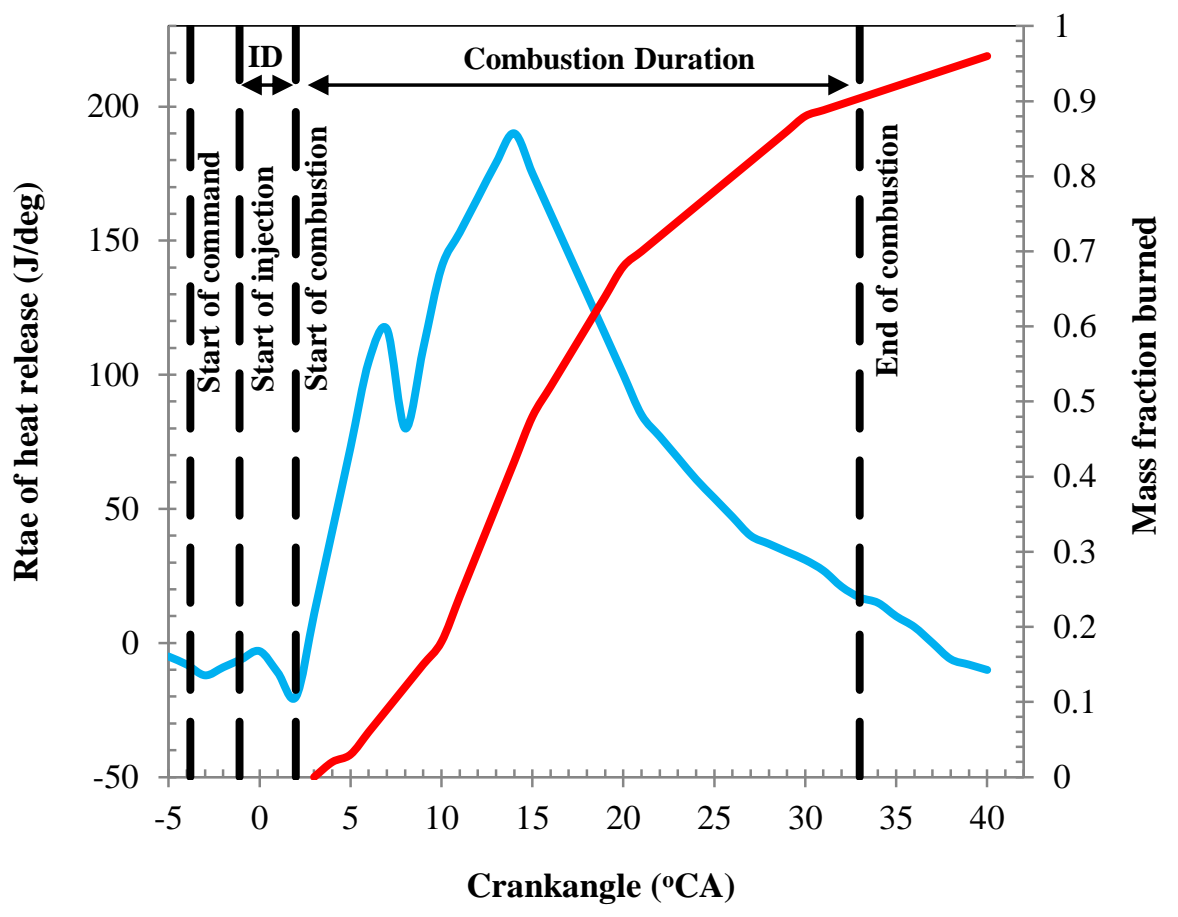

Rate of haet release

Mass fraction burned 


\section{Figure 6}

- Cost of Energy (1.1 US\$) 81.5\%

- Cost of Methanol (0.075 US\$) 5.55\%

Cost of SBE oil (0.16 US\$) $11.85 \%$

- Cost of Catalyst (0.015 US\$) $1.1 \%$

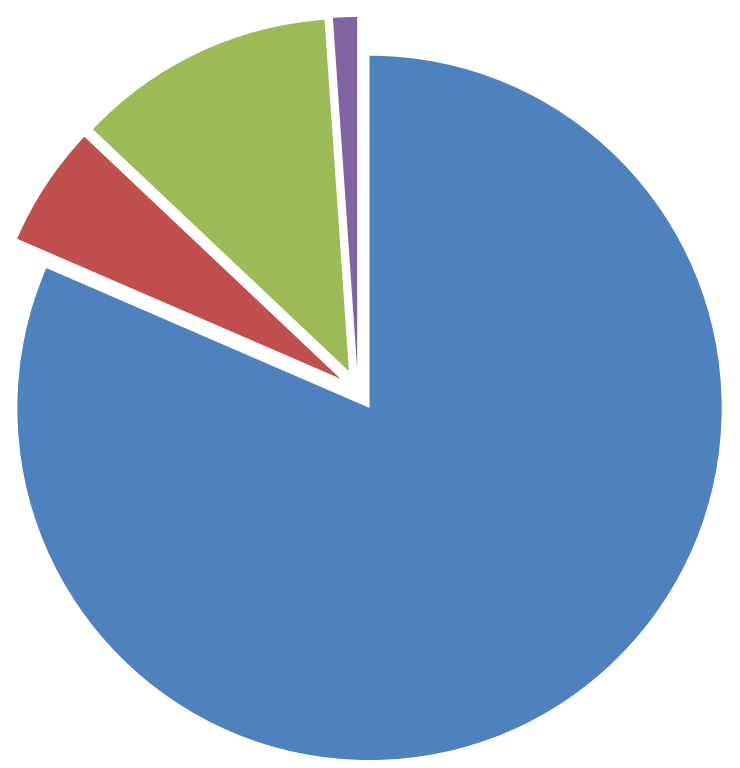




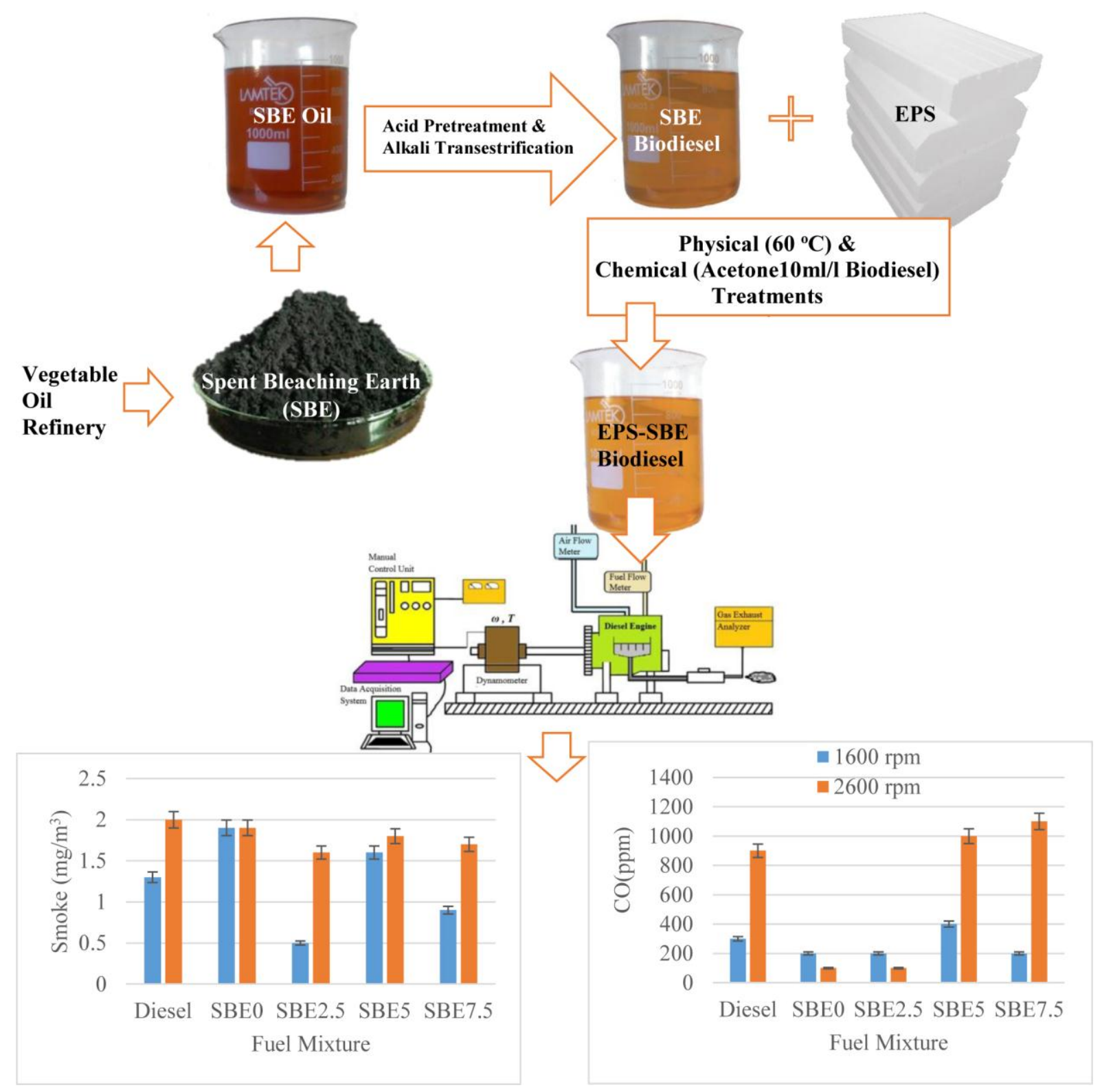

